Crime, Histoire \& Sociétés / Crime, History \& Societies

Vol. 2, n² | 1998

Histoire de la criminalité et de la justice pénale en Amérique latine / Criminal justice history in Latin America

\title{
Looking forward, looking back : judicial discretion and state legitimation in modern Mexico
}

\section{Robert Buffington}

\section{OpenEdition \\ Journals}

Electronic version

URL: https://journals.openedition.org/chs/962

DOI: $10.4000 /$ chs. 962

ISSN: 1663-4837

\section{Publisher}

Librairie Droz

\section{Printed version}

Date of publication: 1 June 1998

Number of pages: 15-34

ISBN: 2-600-00311-8

ISSN: $1422-0857$

\section{Electronic reference}

Robert Buffington, "Looking forward, looking back : judicial discretion and state legitimation in modern Mexico", Crime, Histoire \& Sociétés / Crime, History \& Societies [Online], Vol. 2, n² I 1998, Online since 03 April 2009, connection on 25 March 2022. URL: http://journals.openedition.org/chs/962 ; DOI: https:// doi.org/10.4000/chs.962 


\title{
Looking forward, looking back: judicial discretion and state legitimation in modern Mexico
}

\author{
Robert Buffington'
}

$T$ This essay explores the elite debates surrounding efforts to reform Mexican criminal law that began in the late colonial period and culminated in the 1931 Federal District Penal Code. More specifically, it argues that elite policy makers saw legal reform - in particular the notion of judicial discretion - as a crucial aspect of their efforts to legitimize the state and, in so doing, contributed to the "refeudalization» of the post-revolutionary estado papá.

Cet article explore les débats qui ont entouré, au sein des élites, les tentatives entreprises pour réformer le code pénal mexicain à partir de la dernière période de la colonisation et qui ont culminé en 1931 dans le code pénal du district fédéral. Plus spécialement, il défend la thèse selon laquelle les décideurs politiques considéraient la réforme du droit - et particulièrement la notion de pouvoir discrétionnaire du juge - comme un élément crucial dans leurs efforts pour légitimer l'État. Ils ont par là contribué à la «re-féodalisation» de l'estado papà post-révolutionnaire.

...if we ignore our ancestors, how they thought, felt and acted, we will find ourselves overcome in our own land and we will perish in the deeply tangled roots that impede our resistance to the assaults of more united peoples with more homogeneous aspirations and conscious of their history.

Miguel Macedo ${ }^{2}$

On the surface, Mexican criminal law has closely followed the progressive trajectory depicted in legal historiography ${ }^{3}$. For most scholars, the new and reformed

1 Robert Buffington is an Assistant Professor of History at St. John's University (Collegeville, Minnesota). His publications include: Forging the Fatherland: Criminal and Citizen in Modern Mexico (Lincoln: University of Nebraska Press, forthcoming), Reconstructing Criminality in Latin America, co-edited with Carlos Aguirre (Wilmington, DE: Scholarly Resources, forthcoming); «Los Jotos: Contested Visions of Homosexuality in Modern Mexico», in Daniel Balderston and Donna Guy, (eds.), Sex and Sexuality in Latin America: An Interdisciplinary Reader (New York: New York University Press, 1997); and « Revolutionary Reform: Modernization, Prison Reform, and Executive Power", in Ricardo D. Salvatore and Carlos Aguirre, (eds.), The Birth of the Penitentiary in Latin America: Essays on Criminology, Prison Reform, and Social Control, 1830-1940 (Austin: University of Texas Press, 1996). He is currently working on the "sentimental education " of turnof-the-century Mexican workers. Special thanks to Ricardo Salvatore, Pablo Piccato, Marcus Daniel, Michael Meyer, Donna Guy, Kevin Gosner and the anonymous readers for Crime, History, and Society for their insightful comments.

2 Quoted in Ceniceros (1966, p. 147).

3 This historiography is extensive. See for example Villa and Zambrano (1957) and the bibliography in Refugio González (1983, p. 96-108). 
Penal Codes that followed independence from Spain (1821) represented a series of necessary if halting steps towards a modern legal infrastructure ${ }^{4}$. For legal reformers, modern criminal laws were a harbinger of modern social relations which presented, like the nation's various constitutions, an ideal to which the progressing nation might aspire ${ }^{5}$. This interpretation has much to recommend it: Mexican penologists understood and acted upon the latest international (primarily European) advances in criminal law. Moreover, their legacy persists: Mexico's criminal laws were (and are) as modern as any in the world ${ }^{6}$.

This progressive vision is somewhat deceptive. Just as modernizing discourses like criminology re-articulated traditional concerns about class, race, and gender; penology also exhibited strong ties to Mexico's past'. In the tumultuous post-Independence decades, most liberal penologists - and penologists were by and large liberal - stuck resolutely to revolutionary principles of universal human rights and absolute equality under the law. But with the consolidation of liberal power in the late nineteenth-century, mainstream policy makers began to construct an elitist «scientific politics» that represented - under the guise of Mexicanizing the «metaphysical » Jacobin agenda of mid-century liberals - a return to colonial-style paternalism, albeit with a technocratic slant ${ }^{8}$. And, despite significant changes in public policy after Mexico's great social revolution (1910-1920), paternalism - this time under the auspices of the post-revolutionary estado papá - remained the preferred mode for social and legal reform efforts.

Both visions of Mexican criminal law - one looking forward, the other back were part of ongoing elite efforts to re-legitimize political control in the shifting discursive terrain that announced (or so they hoped) the onset of modernity. These relegitimation efforts began with the «enlightened » reforms of late eighteenth-century Bourbon monarchs (c. 1760s-1810), took a Jacobin turn after Independence as liberals wrested control of the central government from their conservative rivals (by 1867), acquired a technocratic gloss under Porfirio Díaz's autocratic gaze (18761911), and culminated in the post-revolutionary paternalistic populism of Lázaro Cárdenas (1934-1940). In practice, legal modernization often produced contention and disorder - witness the nineteenth-century liberal «reform » laws attacking corporate privilege that raised the considerable ire of the Catholic Church, Army, and incorporated Indian communities. But not all legal reform threatened social order. Mexican penologists argued that criminal law with its far-reaching punitive power, especially over the recently «empowered » lower classes, represented a particularly potent source of political legitimacy. And, as the sovereign "people» came to play

4 The Mexican federal system like its North American counterpart gives individual states the right to promulgate Penal Codes within constitutional guidelines. In practice, the Federal District Penal Code provides the model for most state codes.

5 This is, of course, the classic apologia for failing to realize the more radical provisions of the 1917 Constitution - "obedezco pero no cumplo» as colonial officials typically replied to unenforceable royal decrees.

6 Sold in inexpensive paperback editions by street vendors outside most courthouses and police stations, Mexican criminal laws and procedures are also among the most accessible.

1 For more on the concerns of Mexican criminologists see Buffington (forthcoming) and Piccato (forthcoming).

8 On this shift in Mexican liberalism see Hale (1989). 
an ever larger role in the elite political imaginary (if not in actual politics), popular acceptance of legal authority emerged as an area of special concern?

In this ideologically-charged context, the somewhat arcane legal issue of judicial discretion - the individual magistrate's ability to tailor punishment to suit the crime - became an important site of contestation, among elite policy makers at least, over the nature of the liberal state. The end result, the 1931 federal Penal Code, was a step forward, reflecting the latest international advances in penology; it was also a step back, returning judicial discretionary powers eroded by a century of liberal attacks on « arbitrary » colonial criminal justice. On the surface, increased judicial discretion promised and, doubtless in some cases, delivered a more responsive criminal justice system that buttressed the state's legitimacy much as earlier Bourbon reforms had done in the decades preceding Independence ${ }^{10}$. Moreover, popular pressure responding perhaps to a political system bound together by patron-client relations encouraged and supported the shift ${ }^{11}$. At the same time, increased discretion reinforced a paternalistic approach to state-citizen relations that would come to fruition with tata Cárdenas's consolidation of the estado papá in the late 1930s.

Social theorist Jürgen Habermas has argued that «refeudalization» is an inevitable by-product of the transformation of the Liberal Constitutional State into a Social-Welfare State where «publicity imitates the kind of aura proper to personal prestige and supernatural representation» typical of pre-Enlightenment European monarchies ${ }^{12}$. This was certainly the case in Mexico. Mexican policy makers saw increased judicial discretion - which manifested «the aura proper to personal prestige » of judges - as a form of «publicity » that publicly represented the populist aspirations of the post-revolutionary nation-state. Not coincidentally, the decisive shift occurred at the precise moment (1929) when a newly-constituted official party - precursor to the Partido Revolucionario Institucional (PRI) which still controls the presidency - was poised to abandon traditional modes of democratic representation in favor of a «modern,» corporatist one-party state.

The combination of modernity, nationalism, and paternalism has proven potent if not quite hegemonic. The 1931 Penal Code, although much revised, is still in place. So too, at least for the near future, is the paternalistic political system that produced it. This remarkable durability, especially in a region not known for stability, has been much noted but never adequately explained. And while a definitive explanation for the Mexican «exception » is far beyond the scope of this essay (it's mysteries may well elude scholars for years to come), this brief history of judicial discretion seeks to provide a crucial piece to that larger puzzle by exploring the way elite policy makers used legal reform to forge a truly paternal fatherland ${ }^{13}$.

9 The actual role of the "people $"$ in Mexican politics is a contested issue. Virginia Guedea (1994) argues convincingly that they began to play a prominent role in the capital during the Independence period.

10 See Scardaville (forthcoming).

$"$ On popular efforts by prostitutes and criminals to solicit state intervention see Bliss (forthcoming) and Piccato (1997a).

12 Habermas (1989, p. 195).

13 Seen in this light, the deep historical roots of current president Enesto Zedillo's early efforts to diffuse criticism of his troubled regime with a highly publicized reform of the criminal justice system are very apparent. 


\section{REJECTING THE COLONIAL LEGACY}

Colonial criminal law institutionalized social inequalities by punishing convicted criminals according to their legally-defined social, racial, or corporate status. The shift after Independence to a «liberal » legal system in which all citizens were theoretically equal thus marked a watershed in Mexican penal law.

It was a watershed that would last fifty years! Drawing on French, Spanish, and North American constitutional commitments to «the rights of man and citizen,» Mexico's liberal 1824 Constitution guaranteed legal equality for all Mexican citizens thus apparently ending institutionalized discrimination and bolstering the legitimacy of secession ${ }^{14}$. Ironically, the political instability that followed Independence forced practitioners to fall back on Spanish colonial criminal (and civil) law and procedures, especially the medieval Siete Partidas (1265) and the Novisima Recopilación (1805). Supplemented by stop-gap criminal legislation intended to restore public order, this confusing situation persisted until the promulgation of a Penal Code by the liberal Juárez regime in $1871^{15}$.

But despite post-Independence political disputes between liberals and conservatives that blocked attempts to develop a Mexican Penal Code, the reform and codification of criminal laws was a widely acknowledged desideratum. Early on, Enlightenment-inspired works on crime and punishment had found a sympathetic ear in Mexico. In his world-renowned 1764 essay, Dei delitti e delle pene (On Crime and Punishment), Italian jurist Cesare Beccaria suggested a rationalization of criminal justice that English legal philosopher Jeremy Bentham would later elaborate into a utilitarian moral calculus - «the greatest happiness of the greatest number» - and a notorious but influential proto-penitentiary, the panopticon ${ }^{16}$. As «enlightened " Bourbon reformers and post-Independence Mexican policy makers struggled with the perceived increase in crime that accompanied political and economic modernization, the legal theories of European social reformers like Beccaria and Bentham played an important role in informing the educated public imagination. Even before the break with Spain, Mexican-born (if staunchly loyalist) jurist Manuel de Lardizábal y Uribe had insisted that «nothing is more important to a nation than having good criminal laws because they ensure civil liberty and, in large part, the wellbeing and security of the State». He warned, however, that «there is no enterprise more difficult than the perfection of criminal legislation $"^{17}$.

Such was the case in independent Mexico. In his 1839 Pandectas Hispano Megicanas, Juan N. Rodríguez de San Miguel summarized the practical problems that emerged from the colonial legal legacy:

14 On constitutional guarantees see Rabasa (1990). On European influences on Mexican constitutionalism see Hale (1968).

15 For histories of Mexican colonial and early national criminal law see Macedo (1931); Refugio González (1983, p. 12-108); and Vera Estañol (1900-1902, p. 725-773). Perversely, Spain had a modern liberal Penal Code by 1848 while Mexican jurists continued to use colonial criminal laws. Beccaria (1986). On Bentham's utility principle see especially Bentham (1948). For Michel Foucault (1979, p. 195-228), Bentham's panopticon provided a paradigm for post-Enlightenment surveillance of civil society. The impacts of Beccaria and Bentham on criminology are examined in Monachesi, «Cesare Beccaria» and Gilbert Geis, «Jeremy Bentham in Mannheim (1960, p. 36-67).

17 Lardizábal y Uribe (1982, p. iii). 
Our [legislation] after nearly thirty years of revolution, not only of arms, but of customs, government, and estate, suffers more than anything from the complication, diversity, and uncertainty of the laws... [which] retard the administration of justice, hinder the response and ability of the authorities, and impede the investigation of cases... ${ }^{18}$.

Apart from its unwieldiness, this convoluted legacy, in the biased eyes of liberal reformers, threatened the legitimacy of a new order that promised legal equality to all citizens. Liberal theorist José María Luis Mora even reprinted a Bourbon era critique of colonial criminal justice that warned of the dangers of legal discrimination: «What affection», it inquired:

what benevolence can [castas and indios] feel towards the ministers of the law that only exercise authority in order to send them to jail, the gibbet (picota), the presidio, or the gallows? What bonds can link these classes to a government whose protection they are incapable of comprehending ${ }^{19}$ ?

In an era of political violence that exacerbated elite fears of popular mobilization such warnings seemed prescient; the need to reform criminal law painfully obvious. «Criminal legislation,» Mora's liberal colleague Manuel Otero advised, « is at the same time the foundation and proof of social institutions». And, while recognizing the inevitability of crime, he argued that the conscientious legislator «needs to demonstrate his genius by conquering bad inclinations, setting men on the path of duty... governing society, pushing it towards the good, guiding it to perfection $»^{20}$. For Otero, good criminal laws would not only repress the criminal but instruct the potential citizen thereby ensuring their popular acceptance, a necessary prerequisite to social progress in a modern democratic republic.

One proposed solution was adoption of the jury system. Mora even advocated popular juries in an 1827 «dissertation » for his law degree noting that jurors were less susceptible to corruption than judges and more in tune with the criminal justice system's typically lower-class clientele. "The knowledge of persons», he pointed out,

their habits and customs, their vices and virtues, and their individual character, are beyond the reach of a judge who knows little about them and before whom they necessarily dissemble, as do most of their fellow citizens with whom they [the accused, witnesses etc.] contract the relations that allows them [their fellow citizens on the jury] to know and evaluate the degree of probability or certitude that ought to be given to testimony and motives ${ }^{21}$.

For Mora, then, only an English or North American-style jury of peers could transcend the profound class divisions in Mexican society and provide the understanding and insight necessary to a fair trial.

Concern about popular justice carried over to the liberal 1857 Constitutional Congress where commission members revived Mora's arguments in favor of popular juries. They noted in their initial proposal that « the sovereignty of the people, the

18 Quoted in Refugio González, (1983, p. 49-50).

19 Mora (1986-1988a, p. 63).

20 Otero (1967, p. 653-654).

21 Mora (1986-1988b, p. 250). 
foundation of republican principles, point of departure for all its applications, secure gauge for the solution of all its problems, is incomprehensible, is inconceivable, without the institution of the jury "22. In what was to become a classic riposte, opponents countered that juries were inappropriate for «our population and territory ", because to be effective they required an educated, moral citizenry which «is disgracefully not characteristic of most of our population ${ }^{23}$. Not surprisingly, in 1869 , when legislators amended criminal procedures to include juries for some cases, they compromised; literacy and income requirements effectively excluded lower-class participation $^{24}$.

But in spite of disputes over the extent of popular empowerment, legal reformers clearly recognized the pressing need to reform criminal laws and procedures. They also stressed the importance of popular acceptance of, if not always active participation in, the criminal justice system. In fact, attempts to reconcile (at least discursively) the potentially conflicted requirements of appropriate institutions and popular acceptance became the hallmark of future Mexican criminal jurisprudence. By the mid nineteenth century the terms of the debate had been chosen; the exact meaning of those terms, however, was far from clear.

\section{CODIFYING CRIMINAL LAW}

The promulgation of the liberal 1857 Constitution which included Mexico's first real bill of rights marked the crucial first step toward the codification of Mexican criminal law. The Constitution officially ended many of the more onerous aspects of colonial criminal law: not only legal discrimination, but also most special tribunals, unauthorized arrest, lengthy detention, torture, unlawful seizure of property, and transcendental punishment. Procedure was reformed as well. The Constitution eliminated court fees, making the judicial system economically accessible to all Mexicans. Article 20 guaranteed Mexican citizens accused of crimes the following rights:

I. That they be informed of the motive for the proceeding and the name of the accuser if one existed.

II. That their preliminary statement be taken within forty-eight hours...

III. That they be allowed to confront the witnesses against them.

IV. That they have easy access to the facts needed to prepare their defense.

V. That they and persons they trusted be allowed to testify on their behalf. And, if they had no one to defend them, that they be given a list of public defenders from which to choose ${ }^{25}$.

22 Zarco (1956, p. 316).

23 Ibid., p. 351. Mexico's relative backwardness also served to justify keeping the death penalty until the development of a reformative penitentiary system. Capital punishment was, however, restricted to serious crimes like murder and political criminals, excepting traitors, were no longer eligible for execution. Ibid., p. 1347.

24 Rebollar (1894a, p. XLIX-L and 1894b, p. 8-9).

25 Zarco (1956, p. 1345-1348). Transcendental punishment was directed not just at the individual but at the family as well. The typical transcendental punishment in Spanish colonial law was infamy which carried down to the fourth generation, denying the condemned access to royal favors and public employment. 
Drafters of the 1857 Constitution clearly intended these rights, typical of most nineteenth-century liberal constitutions, to correct the most egregious failures of colonial criminal justice, facilitate popular acceptance of the liberal regime, and set the parameters of subsequent criminal law.

These lofty goals were not easily realized. By incorporating controversial « reform " laws that sought to undermine the considerable power of corporate entities like the Catholic Church and the army, the 1857 Constitution sparked a bloody three-year civil war. With the legal assault on corporations tearing Mexico apart, the liberal push to reform criminal law, a generally well-regarded and non-controversial project, became even more acute. In 1862, with the liberals temporarily victorious, Benito Juárez's Minister of Justice Jesús Terán appointed a commission to formulate a Penal Code for the Federal District and Territory of Baja California. His conservative opponents, however, were far from finished. The successful French invasion in May of the following year and puppet emperor Maximilian's subsequent three-year reign further delayed liberal penal reform efforts. But, following liberal victory in 1867, Juárez reformed his cabinet, appointing former Penal Code commission member Antonio Martínez de Castro as his Minister of Justice and Public Instruction.

Martínez de Castro moved quickly. Just a year later, the Penal Code commission was up and running again ${ }^{26}$. In his 1868 message to Congress, he reminded deputies of the legitimizing potential of reformed criminal laws. "The punishments applied today are truly arbitrary », Martínez de Castro admonished, « and ought to be replaced by others better suited to the nature of the crimes, and which will not deprive prisoners of their modesty, their shame, nor the hope of rehabilitating themselves in the public eye». He added with a characteristic utilitarian faith in the value of public instruction that:

...in publishing a good Penal Code that even the poorest can acquire at little cost, so that they might learn their duties, know the deformity of crime, and advise themselves of the punishments they might incur, one will doubtless see a rapid decline in the number of delinquents ${ }^{27}$.

Appropriately enough, as Minister of Justice and Public Instruction, Martínez de Castro was charged not only with drafting a Penal Code but also with educating the populace so that they could read it. These were the halcyon days of public education in Mexico; although the most notable achievement, Gabino Barreda's founding of the Escuela Nacional Preparatoria with its «scientific » positivist education, benefited mostly elite males. Unfortunately, the immense task of educating the lower classes and thus realizing Martínez de Castro's dream of a didactic Penal Code would quickly prove beyond the means (and possibly the intentions) of the fledgling liberal state. Nevertheless, the desire to win popular acceptance for the criminal justice system, and thus legitimacy for the liberal regime, persisted, and with some success.

The promulgation of the Federal District Penal Code on April 1, 1871 ended the long gestation of Mexican criminal law ${ }^{28}$. As Martínez de Castro had promised, it

26 Ceniceros (1964, p. 182-185). Background on the Penal Code commission is also included in Martinez de Castro (1968, p. 132-133).

${ }^{27}$ Quoted in Piña y Palacios (1968, p. 131).

28 The State of Vera Cruz, generally at the forefront of Mexican criminology and penology, promulgated the nation's first Penal Code on May 5, 1869 but it lacked the prestige and influence of the 1871 Federal District code. 
aspired to be both modern and popular. And, although modeled on the 1848 and 1870 Spanish Penal Codes, even to the point of copying grammatical errors, the Mexican code made a deliberate appeal to nationalist sentiment ${ }^{29}$. In his «Exposition of Motives » Martínez de Castro cited Montesquieu's classic comments on appropriate legislation, a favorite of Mexican jurists, and added his own specific if typically restrained critique of Spanish colonial criminal law. «Formed in large part centuries ago by absolutist governments», he observed, «in times of ignorance and for a different kind of people with different customs and education, [Spanish criminal laws] have no place in independent, republican, and democratic Mexico where equality is dogma, where one enjoys liberties and rights unknown in the times of Alonso el Sabio ${ }^{30}$. This Penal Code was, for its principal author, both conceptually up-to-date and eminently suited to Mexico's unique historical and geographical situation, two crucial criteria at least for elite acceptance.

The code was also designed to attract the popular support deemed crucial to domestic tranquility. After the fifty years of post-Independence turmoil, Martínez de Castro concluded, «the authorities have not been able to count on public cooperation, and because of this they have been unable to guarantee the public security which is essential to the prosperity of the arts, industry, and commerce ${ }^{31}$. A wellordered, easily accessible Penal Code that promised speedy, impartial, moderate justice; that reformed prisons, ended presidio confinements, and forced labor seemed just the remedy for Mexico's ills. The 1871 Penal Code thus attacked the perceived essence of the colonial criminal justice system: inhumane punishment and excessive judicial discretion which encouraged arbitrary justice.

To ensure impartiality and moderation, the code provided an elaborately calibrated system of punishments that left little room for the capricious exercise of judicial discretion by an individual magistrate. A product of classic criminology via English legal theorist Jeremy Bentham, this punitive calculus reflected Martinez de Castro's profound faith in human rationality ${ }^{32}$. Article 4 stated plainly that «Crime is: the voluntary infraction of a penal law, doing that which it prohibits or neglecting to do that which it demands ${ }^{33}$ (CP: 7 . My italics). Further, those without the ability to reason - young children, the insane, the senile, deaf mutes, and even loyal servants acting under orders - lacked the requisite «criminal responsibility» or «imputability » and could not be convicted of a crime ${ }^{34}$ (CP: 13-14, 47).

Assuming a rational, «responsible» criminal meant that punishments could be rationalized as well. And, to ensure that judicial rationality was exercised in the national interest rather than in the personal or class interests of an individual magistrate, this system was deliberately formulaic. For example, the Penal Code recognized four levels of criminal acts - planned, intended, frustrated, consummated - each punished with increasing severity (CP: 10). It also recognized four classes of attenuating and aggravating circumstances with each circumstance augmenting or dimi-

\footnotetext{
29 The grammatical errors are noted in Almaraz (1941, p. 15-16).

30 Martínez de Castro (1931, p. 132).

31 Ibid., p. 133.

32 See especially Bentham (1948). This work was first published in 1789.

33 Código Penal... (1890) (Hereafter CP; specific page references are cited in the text).
}

34 If they represented a danger to society they could, under certain circumstances, be institutionalized in asylums or special juvenile facilities. 
nishing punishment by a set proportion according to its class. Attenuating circumstances could be simply «good prior customs » or anything that indicated a unintentionally diminished capacity to reason such as involuntary drunkenness or gross «ignorance». Conversely, aggravating circumstances might include the use of violence or disguises, taking advantage of a riot, abuse of confidence, or simply having had enough education to know better (CP: 14-21). Recidivism, always a source of grave concern, was a special aggravating circumstance and could drastically increase punishment especially if the repeat offense was more serious than its predecessor (CP : 58-59). Both lists of circumstances were long and fairly explicit, leaving little apparent room for arbitrary judicial maneuvers ${ }^{35}$. Using these pre-determined formulas, then, a judge need only establish guilt and determine circumstances in order to calculate the proper punishment. In this classic liberal formulation of «rule of law,» rationality was a systemic rather than an individual trait; pre-determined punishments, equally applied, ensured impartiality to a presumably skeptical people accustomed to capricious colonial justice. The extensive section of the Penal Code devoted exclusively to the crimes of public functionaries and legal representatives served a similar redemptive purpose ${ }^{36}$ (CP: 221-236).

Judicial discretion, although severely limited, was not without its place in this rationalized system. A judge could grant a «preparatory liberty (libertad preparatoria) under police supervision to inmates who exhibited «good behavior» in prison and who had the means to support themselves once released. In keeping with its rationalist premises, the Penal Code defined good behavior as «positive acts » on the part of the inmate, «habits of order, work, and morality, and especially having dominated the passion or inclination that led to crime ${ }^{37}$ (CP:34). Preparatory liberty thus rewarded normative behavior and complemented the rehabilitation process begun in prison. But the Penal Code limited even this grant of judicial discretion to a simple decision for or against the inmate ${ }^{38}$. Although it clearly recognized the need to individualize punishment, the manifesto of later positivist-inspired penology, the 1871 Penal Code tightly controlled judicial discretion. Liberal «memories» of arbitrary colonial justice were still too fresh.

\section{PRESERVING THE STATUS QUO: THE PORFIRIAN REVISIONS}

This reluctance diminished as the century waned. Firmly in power after the defeat and execution of Maximilian in 1867, fin-de-siècle liberal presidents Benito Juárez, Sebastián Lerdo de Tejada, Porfirio Díaz, and Manuel González encouraged a more authoritarian brand of liberalism that they hoped would undermine the power of regional strongmen (caciques) and accelerate national economic development. The growing influence of positivist ideas in Mexico - an eclectic mixture of Comtean scientism and Spencerian social darwinism - especially during second half of

35 Writers of official texts like Martínez de Castro conscientiously avoided institutionalizing class biases. Nevertheless, in practice, evaluating an attenuating circumstance like "good prior customs" inevitably reflected the prejudices of the presiding magistrate.

36 The ideological impact of these provisions would have been greatly enhanced had Mexican educators realized Martínez de Castro's vision of a literate general public.

37 Libertad preparatoria could include up to half of the inmate's original sentence.

38 Macedo and Ceniceros (1928, p. 26). 
the Porfiriato (1876-1911) provided ideological justification for oligarchical rule (although in a nominally liberal context) and encouraged the development of a «scientific politics» appropriately administered by elite technocrats or científicos.

In spite of its enormous prestige, however, Positivism had little immediate effect on Mexican criminal law. Although very much aware of the latest advances in European criminology, including the vigorous debate between Italian and French criminologists over the principal source (heredity or milieu) of criminal behavior, cientifico reformers preferred a gradualist approach to penal reform that respected the integrity of the 1871 code in spite of its presumably metaphysical views on crime and punishment. Headed by prominent penologist Miguel S. Macedo, the commission established in 1903 to revise the Penal Code even refused to correct grammatical or stylistic errors in the text unless these errors obscured or distorted its meaning. The commission saw fit only to modify vague language and update laws that had proved either too harsh, too lenient or unworkable in the courtroom. For example, the commission simplified procedures and encouraged fines rather than incarceration for those convicted of public drunkenness while at the same time expanding the penalties and requirements for recidivism and illegal public disturbances ${ }^{39}$. In general, however, commission members saw little reason to do more than « respect the general principles of the 1871 Code, conserve the nucleus of its system and limit [themselves] to incorporating only the new precepts or new institutions whose usefulness had been proven and whose inclusion is demanded by the present social state of the nation ${ }^{40}$. The only significant addition, a North American style parole system (condena condicional), did somewhat further judicial discretion and the individualization of punishment. Even this «innovation», however, retained the rationalist premise that rewarding non-dangerous criminals for good behavior would help reverse their descent into criminality.

In the conservative estimation of penologists like Macedo, practical positivist concerns about appropriate response to social realities outweighed the theoretical concerns of positivist criminology which argued that proper social defense should base the punishment of criminals solely on their «dangerousness» to society. Thus the Porfirian Penal Code revisions, finally completed in June, 1912 during Francisco Madero's troubled presidency, modified rather than revised Martínez's liberal $\operatorname{code}^{41}$. In his chapter on Mexico's «judicial evolution" in the ambitious Porfirian positivist history, México: su evolución social, Jorge Vera Estañol explained this legal conservatism in social darwinistic terms. «An abyss», he observed, «divides societies whose progress is intrinsic from those that have managed it thanks to the irresistible contagion of foreign institutions ». He added pessimistically that «only time is capable of serving as a gigantic bridge to a vigorous race ${ }^{42}$. For Porfirian penologists, the liberal legal revolution that overthrew the colonial legal system

39 Secretaría de Justicia (1913, p. 28 (gambling), p. 57-60 (public disturbances), p. 71-90 (drunkenness)). The commission recommended that habitual criminals, including vagrants and beggars, be transported to a penal colony (Ibid.,p. 383). And even those convicted of habitual drunkenness were allowed only two attempts at rehabilitation before being transported. (Ibid., p. 90).

40 Quoted in González de la Vega (1981, p. 22).

4) Revolutionary turmoil prevented the incorporation of the Porfirian revisions into the Penal Code although the publication of the four volume Trabajos de revisión del Código Penal ensured that they played a role in later revision efforts. See Villalobos $(1948$, p. 155).

42 Vera Estañol (1900-1902, p. 772). 
represented a premature, ill-considered (although most agreed necessary and inevitable) attempt to radically alter Mexican society. Conversely, this time around, an appropriate response would respect social realities including the need to modernize (socially at least) in a gradual, controlled fashion. Legal evolution would occur in Mexico but slowly so as not to disturb newly won « order and progress». The argument was positivistic but reflected a profoundly conservative positivism that defined social change in nearly glacial terms. Paradoxically, by the early years of the twentieth century, the post-Independence liberal legal revolution had become a permanent fixture of the social landscape, an institution to be carefully nurtured and perhaps judiciously modified but never unduly shocked or uprooted. The Mexican Revolution would change all that.

\section{PUNISHING THE CRIMINAL: THE REVOLUTION AND POSITIVIST PENOLOGY}

Disorganized and unsystematic, Porfirian criminology had been ill-equipped to challenge the legal establishment. A criminologist of sorts himself, Macedo had publicly criticized liberal penology and lauded the «ever broadening horizons " opened by the «study of crime as a natural phenomenon ${ }^{43}$. Positivist criminology, however, had more impact on his discourse than his Penal Code reforms. A traditionalist at heart, he continued to use classical legal texts in his law classes ${ }^{44}$. Nevertheless, the professionalization of criminology and the consolidation of the scientific criminological paradigm in the years following the Revolution had made the positivist criminological agenda more difficult to ignore ${ }^{45}$.

In the eyes of most knowledgeable observers, positivist critiques called into question the continued legitimacy and, by extension, the legitimizing potential of Mexican criminal law. Coming on the heels of a massive social revolution that promised social justice for all Mexicans, the push for legal reform to complement political change took on still greater intensity. Even Macedo's conservative colleague, law professor Antonio Ramos Pedrueza began his revolutionary-era course in penal law with a detailed discussion of the relative merits of classic and positivist criminology that attacked the underlying premises of Mexican criminal law ${ }^{46}$. Taking inspiration from Italian criminologist Enrico Ferri, Ramos concluded that the rational criminal, the foundation of classic criminology, had never existed. «Observed reality in prisons and asylums affirms that delinquents are abnormal», he noted, «...admitting nevertheless that they are very different and that the passage from hardened criminal type to normal human type is not a brusque transition but a series of gradations, just as in animal species ». After positivist criminologists' discovery of

43 Macedo (1954, p. 381). In this speech, Macedo argued in favor of «conditional » punishments but added that Mexico lacked the institutional infrastructure - modern prisons, trained personnel, effective criminal procedures - to support a parole system (ibid., p. 394-395).

Ceniceros (1966, p. 142).

45 On the practical implications of revolutionary penal reform see Piccato (1997b).

46

Pina y Palacios (1961, p. 636) and Pedrueza (1961, p. 637-655). In 1921, UNAM rector José Vasconcelos dismissed Ramos from his professorship in penal law for publicly eulogizing Agustín de Iturbide to students at the Escuela Nacional Preparatoria. Both Macedo and Ramos were among that school's illustrious alumni. 
the criminal's inherent abnormality (typically signified by irrational behavior), Ramos argued that subsequent legislation and judicial practice should seek to judge not the "criminal and the crime » but the «criminal in the crime» ${ }^{47}$. The positivists" insistence on individualizing punishment in order to better rehabilitate the criminal but especially to «defend » society by keeping dangerous criminals off the streets (regardless of the severity of their actual crime) was beginning to make serious inroads into mainstream Mexican legal theory as well. José Angel Ceniceros, acting as adjunct professor in a 1926 course in penal law directed by his mentor Miguel Macedo, noted that «crime, more than an act is a state [of mind] ${ }^{48}$. The translation of positivist theory into practice lacked only opportunity.

That opportunity came in 1925 when President Plutarco Calles created revisory commissions to bring Mexico's various legal codes into line with the 1917 Constitution and with post-revolutionary expectations. A year later, the fateful addition of committed positivist José Almaraz to the Penal Code commission (which included Ramos Pedrueza) marked the beginning of a frontal assault on classical criminology and the 1871 Penal Code. In Almaraz's eyes, Mexico's latest perceived crime wave testified to the ineffectualness of the existing Penal Code which he blamed on its theoretical poverty. "The classical school,» Almaraz recalled, «had become completely bankrupt and could no longer serve as the foundation for penal legislation ${ }^{49}$ (ECP : 11-12). With this blunt assessment, the revisory commission set out to bring Mexican criminal laws into line with modern positivist penal theory.

What the commission attempted was nothing less than a theoretical revolution in Mexican criminal law. As positivists, they insisted on contextualizing crime. The classical school, Almaraz observed with some exaggeration, «forgets the criminal and concerns itself only with the crime committed». Attempting «absolute mathematical equality between crime and punishment ", he insisted, often resulted in inappropriate punishments. This formulaic system inevitably released unreformed dangerous criminals back into society, while at the same time it condemned relatively harmless incidental criminals to the corrupting influence of prison confinement. Under the classical legal regimen, Almaraz declared, «the toxic current of crime grows day by day » (ECP : 14-15). As an antidote to this misguided rationalism, the commission argued for a fundamental redefinition of the criminal act as «a natural product, born not of free will but of physical, anthropological, and social factors » (ECP : 18). The theoretical inspiration was probably French sociologist Emile Durkheim whose influential 1893 Rules of the Sociological Method had insisted that crime was a normal «social fact» in all human societies. Moreover, with a purportedly revolutionary regime in power, lingering social inequalities - exacerbated loy Porfirian abuses - provided an easy scapegoat for Mexico's latest crime wave and helped legitimize the new political order bent on their eventual elimination.

Having determined the causes of crime, the commission then sought to redefine criminal responsibility. For classical penology, establishing the rationality of the individual criminal was a prerequisite to punishment; to positivists like Almaraz, this seemed absurd. «Given that infractors reveal hereditary or acquired, permanent or temporary bio-psychic anomalies,» Almaraz argued, «the foundations of a fight

47 Ibid., p. 641, 653. My italics.

48 Macedo and Ceniceros (1928, p. 219).

49. Almaraz (1931); Hereafter ECP : specific page references are cited in the text. 
against delinquency based on moral responsibility disappear and the entire classical edifice comes crashing to the ground ». He concluded that healthy, «rational » societies, in a social darwinistic spirit of self preservation, protected themselves from all threats regardless of motivation. In fact, this conflation of social health and social rationality effectively denied rationality to any individual «organism » that threatened society's collective well-being. Recognizing this fundamental discursive shift, Almaraz proposed that «social responsibility » replace moral responsibility and that «sanctions » substitute for punishments in a more workable, non-moralistic system of «social defense» (ECP : 18-19).

This discursive shift carried two important corollaries. First, by privileging an abstraction, criminality, over the more narrow category of lawbreaker it encompassed many more people. "An individual can be dangerous to society », Almaraz advised, « even before committing a crime (lesionar un derecho)» and he especially singled out alcoholics, drug addicts, vagrants, beggars, and even paranoids (ECP : 20). Mexican elites had traditionally persecuted most of these groups. Nevertheless the legal sanctioning of potentially (but not always technically) criminal categories punishing states of mind rather than pre-defined criminal acts - was one inevitable and potentially portentous consequence of using social defense as the principal criteria for criminal law. "All law is essentially doctrine», Almaraz reminded his readers, «... politically personalized doctrine» (ECP : 12. His italics).

The second corollary, typical of positivist endeavors, was a considerable expansion in the prestige and scope of scientifically trained experts. Any serious attempt to transcend a relatively simple determination of guilt and to evaluate the dangerousness (estado peligroso) of an individual criminal required considerable expertise. Almaraz warned that «the prior and indispensable study of the delinquent's integral personality demands functionaries and judges trained in the modern doctrines of criminal psychology" among which he included everything from endocrinology to the interpretation of tattoos (ECP: 100). This new requirement was clearly self-serving and designed to insinuate criminology into the justice system by creating professional spaces for trained criminologists. It also ensured their domination of legal discourse. To this end, the 1929 Penal Code established a Supreme Council of Social Defense and Prevention to oversee the entire federal prison and detention system, supervise the «individualization of punishment,» and ensure that criminal justice personnel upheld the basic tenets of social defense (ECP: 54).

Other innovative features appeared as provisions of the new Penal Code. For example, in an effort to individualize punishment - to make the punishment suit the criminal rather than the crime - the revisory commission greatly expanded the alternatives to incarceration by broadening the parole system (condena condicional) and substituting fines for short sentences. To support these changes, the commission revived the time-honored complaint about corrupting prisons. «It is necessary to oppose short incarcerations », it advised, « which in their current form fail to correct, intimidate, or inoculate; but which oblige the first-time offender to transform himself into a professional [criminal]» (ECP : 53). Therapeutic solutions, especially for juveniles and the insane, were favored over simple incarceration and, in keeping with the principles of social defense, sanctions against the dangerous criminally insane could be extended indefinitely. Not surprisingly, this broadening of «sanctions » required not only more professional training but greater judicial discretion in 
sentencing as well, albeit under the watchful eye of the Supreme Council and its ever-vigilant president, José Almaraz.

Liberal human rights provisions of the 1917 Constitution, however, thwarted efforts to formulate a truly positivist Penal Code. Punishing everyone judged dangerous to society clearly violated basic constitutional guarantees. «Since the Constitution prevents the realization of all the logical consequences that can be derived from the adoption of the principle of social defense,» Almaraz noted with regret, «the Revisory Commission had to forego many important innovations » (ECP : 49). This gave the new Penal Code a «transitory» character, at least in the eyes of its principal architect. These gaps between theory and practice also provided future opponents of the code an easy avenue of attack; an avenue that they quickly exploited.

\section{PRAGMATISM OVER POSITIVISM: THE LEGAL ESTABLISHMENT RESPONDS}

Legal establishment attacks on the 1929 Penal Code were swift and devastating. Critics complained that the new code, for all its theoretical innovations was inconsistent, unnecessarily radical, and unacceptably impractical. Future professor of criminal law Juan José González Bustamante, a young lawyer at the time and a former Macedo student, recalled Almaraz's discursive revolution as:

simply a conceit (snobismo), an irresponsible word play, because Penal Law is fundamentally a protector of society and punishment is essentially retributive and is imposed as a necessary evil in order to procure the conservation of social order... If the means employed, whether it is called punishment or sanction, produces even a little suffering on the part of its recipient we must conclude that it is indeed a punishment... ${ }^{5}$

Other critics lauded Almaraz's efforts to supplant out-dated classical precepts but argued that the new code failed to live up to its promise. One observer noted that «the code suffered from redundancies, occasional duplicity of concepts, contradictions and difficulties of application ${ }^{51}$. These obvious defects encouraged an overdetermined criticism that attacked the code's internal contradictions, theoretical foundations, and constitutionality. Another critic, for example, observed that although the code was purportedly based on theories of social defense and dangerousness in fact it retained the «objective criteria» of classical penology, in particular the formulaic system of aggravating and attenuating circumstances of the 1871 Penal Code. Also, its expanded system of sanctions included a confusing table of indemnizations and an elaborate system of fines based on income which made administration time-consuming and difficult ${ }^{52}$. González added that condemning «delinquents, the insane, idiots, imbeciles or those who suffer any other debility, illness or mental anomaly» to indefinite internment was «a wise security measure but contrary to dictates of the Constitution ${ }^{53}$. Most critics agreed on the need to bring

\footnotetext{
González Bustamante (1957, p. 110).

Anaya Monroy (1956, p. 794).

González de la Vega (1981, p. 23-24).

González Bustamante (1948).
} 
the Penal Code into line with modern criminological theory. Many, however, insisted that the 1929 code had missed the point, promising a theoretical innovation that it failed to deliver and which was furthermore unsuited to Mexico's social and constitutional realities. Not coincidentally, these defects also undermined its ideological potential.

In the face of this barrage of criticism, interim president Emilio Portes Gil quickly established a new revisory commission. To avoid future dissension and resistance, the five voting members of the commission represented the heart of the capital's legal establishment: the Interior Ministry, Attorney General of the Republic, Attorney General of the Federal District and territories, Federal District Superior Court, Penal Courts. Representatives of the Supreme Council of Social Defense and Prevention and the previous revisory commission were in attendance but only as non-voting advisors ${ }^{54}$. The two most prominent voting members, José Angel Ceniceros and Luis Garrido, were Macedo acolytes and vocal critics of the 1929 code.

Given the practical orientation and relative conservatism of the new revisory commission, the repudiation of Almaraz's dogmatic positivism was inevitable. Garrido noted that:

most of us had been brought up on the Comtism of the old National Preparatory School and viewed with great sympathy the survival of positivism in the modern schools of penology, without finding feasible the construction of a code based exclusively on positivist principles ${ }^{55}$.

The stated principles of the 1931 Penal Code then included not only the standard admonition to simplicity and clarity but a promise to modernize only « up to the point permitted by our constitutional framework, our judicial traditions, and our social and economic conditions ${ }^{56}$. Commission spokesman Alfonso Teja Zabre argued that:

No school, doctrine, or penal system can serve as the integral foundation of a Penal Code. It is possible only to follow an eclectic and pragmatic tendency which is to say practical and realizable ${ }^{57}$.

Thus instead of positivist dogma, commission members focused on «pragmatic" means. Specific goals included a simplification of procedures, the effective reparation of damages, the individualization of punishment, a decreased reliance on abstract ethical standards (casuismo), and an increase in judicial discretion within constitutional limits ${ }^{58}$. The first two of these five goals addressed the practical failings of the 1929 code, the next two restated positivist critiques of classical penology. The last goal - increased judicial discretion - represented the new Penal Code's principal innovation.

$\$ 4$ Anaya Monroy (1956, p. 795-796).

55 Garrido (1947, p. 58).

56 From Alfonso Teja Zabre, «Exposición de Motivos presentada al Congreso Jurídico Nacional reunido en la ciudad de México en mayo de 1931 a nombre de la Comisión Revisora de las Leyes Penales». Quoted in Anaya Monroy (1956, p. 799).

57 Quoted in Vivo (1937, p. 452).

58 Anaya Monroy (1956, p. 800). 
Articles 51 and 52 codified this increase in judicial discretion. Article 51 advised judges «inside legally-fixed limits» to take under consideration both «external circumstances " and "the peculiarities of the delinquent». Article 52 suggested that along with the traditional mitigating circumstances judges also consider «the special conditions in which [the delinquent] found himself at the moment the crime was committed and other personal antecedents and conditions... that demonstrate his greater or lesser dangerousness (temibilidad) ${ }^{59}$. Ceniceros and Garrido even suggested that the positivist motto, "There are no crimes only criminals », should be modified to «There are no criminals only men ${ }^{60}$. This mixture of traditional and modern, liberal and positivist, concerns typified the self-consciously pragmatic nature of the new code.

Like each of their predecessors, the supporters of the 1931 code argued that the new Penal Code was the first to reflect national realities. One observer noted that the 1931 code «modestly but firmly develops its desiderata in accordance with naked Mexican reality... recognizing, organizing, and balancing reality itself $"{ }^{61}$. Another remarked that:

The division of classes and castes by economic and racial differences in Mexico, causes grave difficulties in the application of penal laws, especially for unassimilated indigenous groups... The only recourse is to simplify norms and procedures, prescribing broad and generic regulations that effectively permit the individualization of sanctions $\mathrm{s}^{62}$.

The argument that culturally and racially heterogenous Mexico required greater judicial latitude accorded with post-revolutionary concerns about addressing the needs of the now mobilized popular sectors. While the 1929 code had attempted a re-theorization of criminal law that appealed primarily to elite modernizers, the drafters of the 1931 Penal Code sought a broader audience. By individualizing punishment, they not only protected society from dangerous criminals but protected relatively harmless offenders from an arbitrary, mechanistic justice that even their positivist predecessors had been unable to supplant. To this end, the new code broadened the range of punishments and abandoned the elaborate calculus of aggravating and attenuating circumstances that had characterized the two previous codes.

The expanded discretionary powers of the judge permitted a flexibility impossible under previous Penal Codes. The ideological benefits of a more responsive justice system were obvious. Previously marginalized groups could now hope for clemency from a sympathetic if paternalistic judge - a throwback to the colonial tradition of royal mercy preserved perhaps in more informal justice systems and thus eminently suited to perceived Mexican social realities ${ }^{63}$. The international vogue for state socialism and the desire to institutionalize (and thus control) popular justice doubtless encouraged paternalistic solutions as well.

In this case at least, modernity and tradition were not necessarily mutually exclusive. Garrido's three criteria for the Penal Code included consideration of «the

\footnotetext{
59 Quoted in González Bustamante (1957, p. 112).

60 Quoted in Vivo (1937, p. 452).

61 Quoted in Anaya Monroy (1956, p. 803).

62 González de la Vega (1981, p. 31).

63 On royal mercy see MacLachlan (1988, p. 1-20). On informal justice see Piccato (1997a, chapter 5).
} 
Mexican juridical tradition... the doctrines and sentiments of the people... [and] the conditions of Mexico's collective life». He added that "the work thus realized sought to establish itself in human terms... in a dynamic relation between penal norms and social reality (realidad del ambiente) ${ }^{64}$. In fact these apparently contradictory sources enhanced the 1931 code's ideological possibilities. Because it could appeal to both modernizers and traditionalists, paternalistic discretionary justice seemed the ideal solution to the admittedly complex and contradictory legitimation problems generated by a wildly heterogenous society. Theoretically at least, individual judges could tailor the law to the social, cultural, and even racial circumstances of their clientele.

Some observers recognized potential dangers. Reviving traditional liberal concerns, one commentator warned that « judicial discretion requires a broad understanding on the part of those charged with applying the law, in order that it not turn into arbitrariness ${ }^{65}$. The possible dangers of paternalism, however, seemed a small price to pay for the popular acceptance that would presumably result from a more flexible criminal justice system. «A fundamentally humane justice», Garrido advised, «... will take into account the sensibilities of the transgressor", adding that, "punishing a man of exquisite sensibilities is not the same as punishing a calloused and crude man ${ }^{66}$. The argument could have come from Lardizábal himself. By the third decade of the twentieth century colonial legal institutions had receded far enough into the historical past to be viewed with a certain dispassionate nostalgia; the dangers of arbitrary justice somewhat mitigated by the assumed benefits of a paternal state.

The paternalism implicit in individualizing punishment was nothing new. Almaraz's code, for example, had fostered the paternalistic pretensions of positive criminology and by extension the place of positive criminologists in the criminal justice system. The Supreme Council of Social Defense and Prevention's central role in ensuring ideological correctness, however, had rankled the legal establishment. His opponents, most of them judges trained in criminology, had resisted this oversight for both practical and professional reasons; it created administrative problems and it usurped their authority. Increased judicial discretion, on the other hand, transferred that authority from the Supreme Council (which subsequently dropped the «supreme» from its title) to the judges themselves. This represented a Pyrrhic victory for positive criminology: while it did permit judges greater latitude to individualize punishment, the insistence on observing constitutional forms and thus metaphysical liberal notions of human rights precluded any legal justification for a comprehensive program of social defense ${ }^{67}$. Consequently, after 1931, criminology became the handmaiden rather than the ultimate arbiter of the modern Mexican criminal justice system. And again, theoretical inconsistencies - the mish-mash of liberalism, state socialism, and neo-paternalism masquerading as "pragmatism» (or even Hegelian synthesis) - probably enhanced the 1931 Penal Code's ideological potential by appealing to a broad social spectrum for a wide variety of reasons ${ }^{68}$.

64 Garrido (1947, p. 64-65).

os González Bustamante (1948).

66 Garrido (1947, p. 67).

67 Jose Almaraz referred sarcastically to the new code as an «accumulation of narrow empiricisms » in his Algunos errores y absurdos de la legislación penal de 1931 (1941, p. 14).

68 For specific examples of popular efforts to manipulate the post-revolutionary criminal justice system see Bliss (forthcoming) and Piccato (1997a). 


\section{CONCLUSION}

Evaluating the practical impact of legal reforms on the Mexican criminal justice system is considerably more difficult than determining its ideological contribution. Mexican criminal justice, like criminal justice in general, retains an important measure of its legitimacy through an inherent conservatism that respects the traditional expectations of its practitioners and clients. This conservative tendency must be acknowledged. When change occurs, its occurs most often at the ideological rather than the practical level; traditional forms take on new content without seriously affecting long-standing legal ritual. Whatever its practical consequences, drafters of the 1931 Penal Code, most of them judges themselves, returned limited discretionary powers to presiding magistrates so that they might better exercise a presumably flexible and benevolent judicial paternalism - a ideological harbinger of, perhaps even a rehearsal for, an estado papá whose supremacy is only now under serious challenge.

Robert Buffington,

St. John's University

History Department

Collegeville, MN 56321 - USA

E-Mail : rbuffington@csbsju.edu

\section{REFERENCES}

Aguirre, C., Buffington R., (eds.), Reconstructing Criminality in Latin America, Wilmington, DE, Scholarly Resources (forthcoming).

Almaraz, J., Exposición de motivos del Código Penal promulgado el 15 de diciembre de 1929. Parte general, México, 1931.

Almaraz, J., Algunos errores y absurdos de la legislación penal de 1931, México, 1941.

Anaya Monroy, F., El Código Penal de 1931 y la realidad mexicana, Criminalia, 1956, 22, p. $1-12$.

Beccaria, C., On Crimes and Punishments (trans. David Young), Indianapolis, Hackett Publishing Co., 1986.

Bentham, J., An Introduction to the Principles of Morals and Legislation, New York, Hafner Publishing, 1948.

Bliss, K.E., «Guided by an Imperious Moral Need »: Prostitutes, Motherhood and Nationalism in Revolutionary Mexico, in Aguirre, C., Buffington, R., (forthcoming).

Buffington, R., Forging the fatherland. Criminal and citizen in modern Mexico. Lincoin, University of Nebraska Press (forthcoming).

Ceniceros, J.A., Miguel S. Macedo, maestro y jurista, Glosas históricas y sociológicas, México, Ediciones Bota, 1966.

Ceniceros, J.A., Vida y pensamiento de Antonio Martínez de Castro, Criminalia, 1964, 30, 3 , p. 182-185.

Código Penal para el Distrito Federal y Territorio de la Baja-California sobre delitos del fuero comün, y para toda la República sobre delitos contra la Federación, Madrid, Establecimiento Tipográfico de Pedro Núñez, 1890.

Foucault, M., Discipline and Punish: the Birth of the Prison (trans. By Alan Sheridan), New York, Vintage Books, 1979. 
Garrido, L., Celestino Porte Petit y el Código Penal de 1931, Notas de un penalista, México, Ediciones Bota, 1947.

González Bustamante, J.J., Las reformas penales, Universal Gráfico, 1948.

González Bustamante, J.J., El Código Penal de 1931, Criminalia, 1957, 33, 2.

González de la Vega, F., El Código Penal comentado precedido de la reforma de las leyes penales en México, México, Editorial Porrúa, 1981.

Guedea, V., El pueblo de México y la política capitalina, 1808-1812, Mexican Studies/Estudios Mexicanos, 1994, 10, 1, p. 27-61.

Habermas, J., The Structural Transformation of the Public Sphere: An Inquiry into a Category of Bourgeois Society (Thomas Burger and Frederick Lawrence, trans.), Cambridge, Massachusetts, The MIT Press, 1989.

Hale, Ch., Mexican Liberalism in the Age of Mora, 1821-1853, New Haven, Yale University Press, 1968.

Hale, Ch., The Transformation of Liberalism in Late Nineteenth-Century Mexico, Princeton, Princeton University Press, 1989.

Lardizábal y Uribe, M. de, Discurso sobre las penas, México, Porrúa, 1982.

Macedo, M.S., Apuntes para la historia del Derecho Penal Mexicano, México, Editorial «CULTURA», 1931.

Macedo, M.S., La condena condicional. Inovaciones y reformas necesarias para establecerla en México. Discurso leído en la session de 17 de Diciembre de 1900 por el Lic. Miguel S. Macedo, delegado del I. Y. N. Colegio de Abogados de México, Criminalia, 1954, 20, 112 , p. 381-416.

Macedo, M.S., Ceniceros, J.A., Derecho Penal y Procedimientos Penales, programa y conferencias de 1926, México, Escuela Libre de Derecho, 1928.

MacLachlan, C.M., Spain's Empire in the New World: The Role of Ideas in Institutional and Social Change, Berkeley, University of California Press, 1988.

Mannheim H., (ed.), Pioneers in Criminology, London, Stevens and Sons Ltd., 1960.

Martínez de Castro, A., Exposición de motivos del Código Penal promulgado el 15 de diciembre de 1929. Parte general, México, 1931.

Martinez de Castro, A., Exposición de motivos del Código Penal, Criminalia, 1968, 34, 3, p. 132-133.

Mora, J.M.L., Escritos del Obispo electo de Michoacán Don Manuel Abad y Queipo... in Obras completas, vol. 3, Obra política, México, Secretaría de Educacíon, 1986-1988a.

Mora, J.M.L., Disertación formada y leída por don José María Luis Mora, ante el Supremo Tribunal de Justicia del Estado de México para examinarse de abogado.., in Obras completas (vol. 2), Obra política (vol. 2), 1986-1988b.

Otero, M., Indicaciones sobre la importancia y necesidad de la reforma de las leyes penales, in Obras, México, Editorial Porrúa, 1967, vol. 2.

Pedrueza, A.R., Derecho Penal (Lecciones), Criminalia, 1961, 27, 1-12, p. 637-655.

Piccato, P., Criminals in Mexico City, 1900-1931: A Cultural History, Ph.D. Dissertation, University of Texas at Austin, 1997a.

Piccato, P., La experiencia penal de la ciudad de México: cambios y permanencias tras la Revolución, 1776-1931, in Illades, C., and Rodríguez Kuri, A., (eds.), Ciudad de México: Instituciones, actores sociales y conflicto político, 1776-1931, México, El Colegio de Michoacán - Universidad Autónoma Metropolitana, 1997b, p. 81-113.

Piccato, P., Understanding society: porfirian discourse about criminality and alcoholism, in Aguirre, C., Buffington, R., (forthcoming). 
Piña y Palacios, J., El maestro Antonio Ramos Pedrueza, Criminalia, 1961, 27, 1-12, p. 636.

Piña y Palacios, J., Una cláusula del testamento del Presidente Juárez sobre la administración de Justicia que aún no se cumple, Criminalia, 1968, 34, 3, p. 131.

Rabasa, E.O., Historia de las constituciones mexicanas, México, Universidad Nacional Autónoma de México, Instituto de Investigaciones Jurídicas, 1990.

Rebollar, R., Exposición de motivos con que fué presentado a la Secretaria de Justicia el proyecto de reformas al código de procedimientos penales, México, Imp. y Lit. de F. Díaz de Leon Sucesores, 1894a.

Rebollar, R., Código de Procedimientos Penales para el Distrito y Territorios Federales, México, Imp. y Lit. de F. Díaz de Leon Sucesores, 1894b.

Refugio González, M. del, Historia del Derecho Mexicano, in Introducción al Derecho Mexicano, México, Universidad Nacional Autónoma de México, La Gran Enciclopedia Mexicana, 1983.

Scardaville, M.C., (Hapsburg) law and (Bourbon) order: State authority, popular unrest, and the criminal justice system in Bourbon Mexico City, in Aguirre, C., Buffington, R., (forthcoming).

Secretaría de Justicia, Comisión Revisora del Código Penal, Trabajos de revisión del Código Penal, vol. 3, México, Tip. de la Oficina Impresora de Estampillas, 1913.

Vera Estañol, J., La evolución jurídica, in Sierra, J., (ed.), México: su evolución social, México, Ballescà, 1900-1902 (3 vols.), vol. 2, p. 725-773.

Villa, M. de la, Zambrano J.L., Bibliografia sumaria de Derecho Mexicano, México, Universidad Nacional Autónoma de México, 1957.

Villalobos, I., La crisis del derecho penal en México, México, Editorial Jus, 1948.

Vivo, J.A., La reforma penal en México, Criminalia, 1937, 3, 1-12, p. 452.

Zarco, F., Historia del Congreso Extraordinario Constituyente [1856-1857], México, El Colegio de México, 1956. 